\title{
Agronomical, Anatomical and Physical Characterisation of Wood Apple (Limonia acidissima) Fruit and Seed
}

\author{
L. Banupriya ${ }^{1}$ and T. Poongodi Vijayakumar ${ }^{2 *}$ \\ 'PhD Scholar, Department of Food Science and Nutrition, Periyar University, \\ Salem-636011,Tamil Nadu, India; banupathy@gmail.com \\ ${ }^{2}$ Professor and Head Department of Food Science and Nutrition, Periyar University, \\ Salem - 636011,Tamil Nadu, India; poonvija@gmail.com
}

\begin{abstract}
The study aimed to identify the agronomic features of wood apple fruit and physical and anatomical characterisation of wood apple seed. The agronomical features of wood apple were confirmed in Institute of Herbal Science, Plant Anatomy Research Centre, Chennai. The anatomical characteristics of wood apple seeds was determined by polarised light microscopy; physical properties such as seed color, thousand unit mass, dimensions, diameter, sphericity, projected and surface area and aspect ratio were determined and correlated. The result showed that selected wood apple fruit belongs to the family Rutaceae and species L. acidissima. The physical characteristics of wood apple seed such as length, width and thickness was $5.81 \mathrm{~mm}, 3.61 \mathrm{~mm}$ and $1.80 \mathrm{~mm}$ respectively. The longitudinal dimension (length) of the seed was higher than the width and thickness. The average projected area and surface area was found to be $16.47( \pm 0.23)$ and $35.46( \pm 0.60)$ $\mathrm{mm}^{2}$ while the mean volume determined for the seeds was $12.66( \pm 0.45) \mathrm{mm}^{3}$. The anatomical characteristics of wood apple seed revealed that the seeds were brown in colour, oblong elliptical in shape and contains two cotyledons which were plano convex. The cells of the cotyledons are thin walled, polyhedral and are darkly strained. The cells contain many cell inclusions, the starch grains being the major content. The wood apple seed coat (Testa) consists of three zones. The total thickness of seed coat was 200-300 $\mu$ m along the boundary of the middle seed coat occurs a layer of calcium oxalate crystals.
\end{abstract}

Keywords: Agronomy, Anatomy, Physical Dimensions, Wood Apple Fruit, Wood Apple Seed

\section{Introduction}

Wood apple (Limonia acidissima) is the only species of its genus, in the family Rutaceae. The fruits of L. acidissima are well documented for its use in Indian traditional medicine and are commonly known as wood apple, elephantapple, monkey fruit, vilampazham, kathbel and kaitha ${ }^{1-3}$.

Limonia acidissima belongs to Rutacea family is a fruit yielding tree native to India and distributed in dry warm regions of Burma and Sri Lanka and it is frequently grown throughout Southeast Asia and Northern Malaya ${ }^{4}$. Its leaves, bark and fruits have medicinal values and used as traditional medicines for centuries due to their antimicrobial ${ }^{5}$, antifungal ${ }^{6}$ and insulin secretogouge $^{7}$ activities. Wood apple seed is a rich source of protein and oil has not been widely studied for its functional and nutritional quality. The literature on utilization of wood apple seed is very limited. Hence the present investigation was focused on the agronomical features of wood apple fruit, physical and anatomical characterisation of wood apple seed.

\section{Materials and Methods}

\subsection{Wood Apple}

The wood apple (Limonia acidissima) is a globose with a woody brownish pericarp, filled with a dark brown

${ }^{*}$ Author for correspondence 
sub-acid pulp when ripe. The surface of fruit is very rough and covered with white bloom. Seeds are numerous, oblong, embedded in the edible pulp. Botanically, the fruit is hard-shelled, many seeded berry ${ }^{8}$. Ripe wood apple with hard shell, fairly large and globular shaped with soft, fleshy, brownish edible pulp was selected for the study; purchased from the daily market of Salem as a bulk as they are highly seasonal and available during the months of September and March.

\subsection{Agronomical Features}

The agronomical features of wood apple fruit such as its popular name, origin of the variety, fruit maturation, plant height, production and cultivation statistics were collected from the Department of Medicinal and Aromatic Crops, Directorate of Horticulture and Plantation Crops at Salem. The fruit was authenticated by the Botanist in the Institute of Herbal Science, Plant Anatomy Research Centre, Chennai, Tamil Nadu.

\subsection{Wood Apple Fruit Components}

The wood apple fruit components related parameters such as weight of whole fruit, shell, pulp, seed, fiber and seed to pulp ratio were determined in ten randomly selected fruits and averaged.

\subsection{Wood Apple Seed}

The seeds were collected from the pulp in two different methods. The pulp was scooped after breaking the hard shell and seeds were washed with water manually for separation. The seeds were manually separated by washing under tap water in the first method. The seeds were collected separately using the centrifugal juicer (Prestige PCJ 6.0) in the second method. The collected seeds were then sun dried and packed in an airtight polythene bags for further analysis.

\subsection{Physical Characteristics of Wood Apple Seed}

The wood apple seed colour, mass, size and shape were determined as physical characteristics.

\subsubsection{Seed Colour}

The colour of the wood apple seeds was determined $^{9}$. The colour was effectively observed by placing 20 wood apple seed samples on a sheet of white paper. The difference in colour of the pericarp (outer coat of the seed) was recorded.

\subsubsection{Thousand Unit Mass of Seeds}

One hundred units of wood apple seeds were weighed and recorded. 1000-unit mass was calculated by multiplying the mass (g) of 100-unit of the seed by 10 to have 1000 seeds weight ${ }^{10,11}$ and averaged from ten determinations.

\subsubsection{Dimensions of the Seed}

The seeds were randomly picked and dimensions were measured using an vernier calliper having least count of $0.01 \mathrm{~mm}^{12}$. The parameters such as Geometric Mean Diameter $^{13} \mathrm{D}_{\mathrm{g}}=(\text { LWT })^{1 / 3}$, Equivalent Diameter ${ }^{13} \mathrm{D}_{\mathrm{e}}=\sqrt{\frac{L(W+T)^{2}}{4}}$, Sphericity ${ }^{13} \varnothing=\frac{(\mathrm{LWT})^{\frac{1}{3}}}{\mathrm{~L}}, 100$ Arithmetic mean diameter ${ }^{14,15}$ $\mathrm{D}_{\mathrm{a}}=\frac{(\mathrm{L}+\mathrm{W}+\mathrm{T})}{3}$, Aspect ratio $^{16} \mathrm{R}_{\mathrm{a}}=\frac{\mathrm{W}}{\mathrm{L}}$, Projected Area ${ }^{17}$

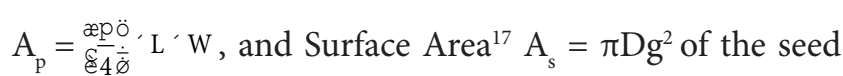
were calculated using the above mentioned expressions.

\subsubsection{Volume (V) of the Seed}

The volume of wood apple seeds was calculated based on the method of Jain and $\mathrm{Bal}^{18}$ through the following equation.

$$
\mathrm{V}=\frac{\mathrm{pB}^{2} \mathrm{~L}^{2}}{6(2 \mathrm{~L}-\mathrm{B})}
$$

Where $\mathrm{B}=(\mathrm{W} / \mathrm{T})^{0.5}$

\subsection{Anatomical Characteristics}

The anatomical structure of wood apple seed was studied by Microscope.

\subsubsection{Preparation of Specimens}

The healthy seed specimens of Limonia acidissima were cast into paraffin blocks ${ }^{19}$.

\subsubsection{Sectioning}

Sectioning and staining were done using standard procedures $^{20,21}$.

\subsubsection{Photomicrographs}

Photographs of different magnifications were taken using Nikon lab photo 2 microscopic unit. Descriptive terms of the anatomical features are as given in standard Anatomy books ${ }^{22}$. 


\section{Results and Discussion}

\subsection{Agronomical Features}

The botanical description of wood apple (Figure 1) was from the family Rutaceae, genus Limonia L. of species L. acidissima under synonyms F. elephantum correa.

\subsection{Wood Apple Fruit Components}

The weight of fruit, shell, pulp, seed and fiber were analysed as components of fruit and the results are shown in Table 1. In wood apple fruit, the shell comprises more weight than pulp and seed. The highest weight of the seed and seed to pulp ratio was found in juicer extraction method.

The seed content of different varieties of mangoes ranges from $9 \%$ to $23 \%$ of the fruit weight ${ }^{23}$ and the kernel content of the seed ranges from $45.7 \%$ to $72.8 \%{ }^{24}$. The pulp and seed accounting for $4 \%$ to $12 \%$ of the total mass of the fruit was obtained from the processing of guava the wood apple pulp also revealed similar percentage of seed compared to mango fruit and higher percentage of seed compared to guava fruit.

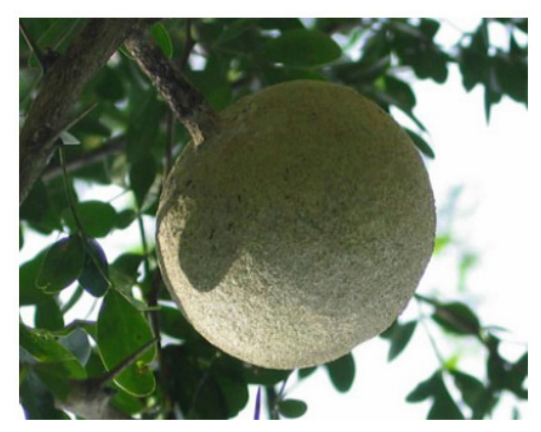

Figure 1. Wood apple fruit.

Table 1. Components of wood apple fruit comparison of extraction method

\begin{tabular}{|l|c|c|}
\hline Parameters & Under Tap Water & Juicer \\
\hline Weight of fruit $(\mathrm{g})$ & $92.6 \pm 2.41(100)$ & $187 \pm 18.64(100)$ \\
\hline Weight of shell $(\mathrm{g})$ & $46.9 \pm 3.92(50.6)$ & $91.6 \pm 14.19(48.9)$ \\
\hline Weight of pulp (g) & $36.7 \pm 5.94(39.6)$ & $18.2 \pm 3.93(9.7)$ \\
\hline Weight of seed (g) & $6.25 \pm 1.71(6.7)$ & $28.2 \pm 7.33(15.0)$ \\
\hline Weight of fibre (g) & $12.9 \pm 2.7(13.9)$ & $35.4 \pm 10.9(18.9)$ \\
\hline Seed/Pulp ratio & $0.16 \pm 0.03$ & $1.59 \pm 0.45$ \\
\hline
\end{tabular}

Values are the average of ten determinants. Figure in parentheses indicates percentage. fruit pulp ${ }^{25}$. According to the juicer method of extraction,

The guava fruit consists of $20 \%$ pulp and $50 \%$ seed core $^{26}$. The highest pulp:seed ratio was recorded in RCG11 genotype guava (94.25) and lowest in RCG-1 genotype guava (27.27) among eleven hybrid varieties of guava ${ }^{27}$. The pulp to seed distribution of wood apple fruit was comparable to guava.

\subsection{Physical Characteristics of Wood Apple Seed}

The colour of wood apple seeds was brown, similar to Achishiru (Nigerian cowpea variety). The physical properties of wood apple seeds determined in this study are shown in Table 2 and Figure 2. The longitudinal dimension (length) of the seed was higher than the width and thickness. The dimensions of wood apple seeds were higher than sesame seed ${ }^{28}$, coriander seeds ${ }^{29}$, Tef seed (Eragrostis tef (Zucc.) Trotter) ${ }^{30}$, chia seeds ${ }^{31}$ and mustard seeds (Sinapis alba L.) ${ }^{32}$ but lower than pumpkin seeds ${ }^{33}$, African yam beans ${ }^{34}$, sunflower seeds (Helianthus annuus L.) ${ }^{35,36}$, rice seed (Oriza sativa) $)^{37}$ and chickpea seeds ${ }^{38}$. Dimensions of the seed are of paramount importance in determining the aperture size of the machine to process the seed. Apart from that, the dimensions could be useful in determining the shape of the seed. Since the three semi-axes of the seed are unequal, the shape of wood apple seed was considered as oblong ellipsoid.

Table 2. Physical properties of Wood Apple Seed (WAS)

\begin{tabular}{|l|c|}
\hline Physical Properties & WAS \\
\hline Length $(\mathrm{mm})$ & $05.81 \pm 0.55$ \\
\hline Width $(\mathrm{mm})$ & $03.61 \pm 0.30$ \\
\hline Thickness $(\mathrm{mm})$ & $01.80 \pm 0.16$ \\
\hline $\mathrm{Dg}(\mathrm{mm})$ & $03.35 \pm 0.20$ \\
\hline $\mathrm{Da}(\mathrm{mm})$ & $03.74 \pm 0.67$ \\
\hline $\mathrm{De}(\mathrm{mm})$ & $06.53 \pm 0.50$ \\
\hline Sphericity (\%) & $57.80 \pm 1.34$ \\
\hline Aspect ratio (\%) & $62.13 \pm 0.15$ \\
\hline 1000 seed mass (g) & $22.60 \pm 0.01$ \\
\hline Projected area (mm2) & $16.47 \pm 0.23$ \\
\hline Surface area (mm2) & $35.46 \pm 0.60$ \\
\hline Volume (mm3) & $12.66 \pm 0.45$ \\
\hline \multicolumn{2}{|l|}{$\begin{array}{l}\text { Dg - Geometric Mean Diameter, Da - Arithmetic Mean } \\
\text { diameter, De - Equivalent Diameter. Values are the } \\
\text { average of ten determinants. }\end{array}$}
\end{tabular}




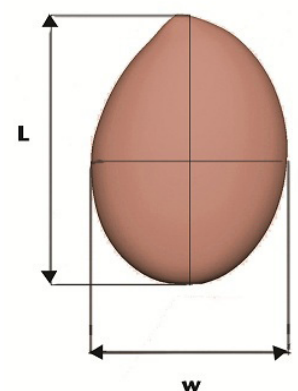

(a)

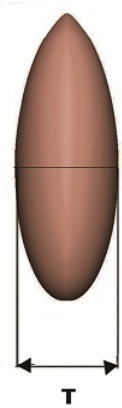

(b)

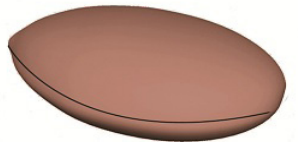

(c)
Figure 2. Characteristic dimensions of Wood Apple Seeds: L, length; W, width; T, thickness. (a) Front view. (b) Side view. (c) Three-dimensional geometry.

The correlation of wood apple seed dimensions in terms of $\mathrm{L} / \mathrm{T}, \mathrm{L} / \mathrm{W}, \mathrm{L} / \mathrm{D}_{\mathrm{g}}, \mathrm{W} / \mathrm{T}, \mathrm{W} / \mathrm{D}_{\mathrm{g}}$ and $\mathrm{T} / \mathrm{D}_{\mathrm{g}}$ were determined and depicted in Table 3. The geometric mean diameter $(3.35 \mathrm{~mm})$ was lower than the length $(5.81 \mathrm{~mm})$ and width $(3.61 \mathrm{~mm})$ and higher than thickness $(1.8$ $\mathrm{mm}$ ). The $\mathrm{L} / \mathrm{T}$ ratio exhibited the highest value, while the $\mathrm{L} / \mathrm{D}_{\mathrm{g}}$ and $\mathrm{L} / \mathrm{W}$ ratio were found similar. The coefficients of correlation showed that $\mathrm{L} / \mathrm{D}_{\mathrm{g}}$ and $\mathrm{T} / \mathrm{D}_{\mathrm{g}}$ were found to be highly significant. This fact indicates that the length and thickness of the seed was positively related to its geometric mean diameter. The length of the seed is positively related to its width, thickness and geometric mean diameter $^{29,31}$. The following general expression can be used to describe the relationship among length, width and thickness of wood apple seed.

$$
L=1.61 W=3.21 T
$$

\subsubsection{Anatomical Characteristics}

The wood apple (Limonia acidissima) seed were 5 or 6 $\times 2.55 \mathrm{~mm}$ in size. The seeds are slimy and brown or dark brown in colour and the seeds are exalbuminous.

\subsubsection{Seed Structure}

The wood apple seed structure was viewed under polarized light microscope for its cross sectional and longitudinal view to study its anatomical features. The seeds were oblong elliptical. There were two cotyledons which were plano convex. The flat sides of the cotyledons were juxtaposed and occur in close proximity within the seed coat (Figure 3(a)). In median longitudinal section, the full embryo with cotyledons and radicle were seen (Figure $3(\mathrm{~b})$ ). The cotyledons were 20
Table 3. Correlation of Wood Apple Seed dimensions

\begin{tabular}{|l|c|c|c|}
\hline Particulars & Ratio & $\begin{array}{c}\text { Correlation } \\
\text { Coefficient }(r)\end{array}$ & p-Value \\
\hline $\mathrm{L} / \mathrm{W}$ & 1.60 & 0.073 & $0.840^{\mathrm{NS}}$ \\
\hline $\mathrm{L} / \mathrm{T}$ & 3.20 & 0.595 & $0.070^{\mathrm{NS}}$ \\
\hline $\mathrm{L} / \mathrm{D}_{\mathrm{g}}$ & 1.72 & 0.839 & $0.002^{*}$ \\
\hline $\mathrm{W} / \mathrm{T}$ & 1.99 & -0.216 & $0.548^{\mathrm{NS}}$ \\
\hline $\mathrm{W} / \mathrm{D}_{\mathrm{g}}$ & 1.07 & 0.340 & $0.337^{\mathrm{NS}}$ \\
\hline $\mathrm{T} / \mathrm{D}_{\mathrm{g}}$ & 0.53 & 0.771 & $0.009^{*}$ \\
\hline
\end{tabular}

*Correlation significant at the $\mathrm{p}<0.01$, NS- Not Significant

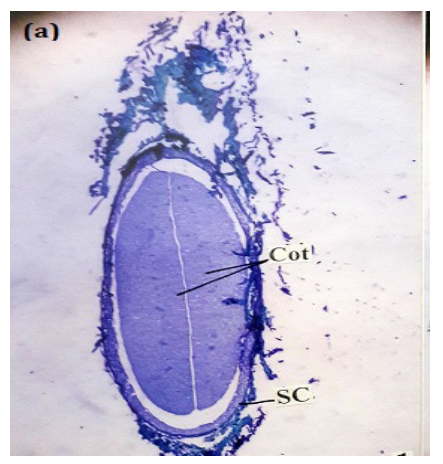

(a)

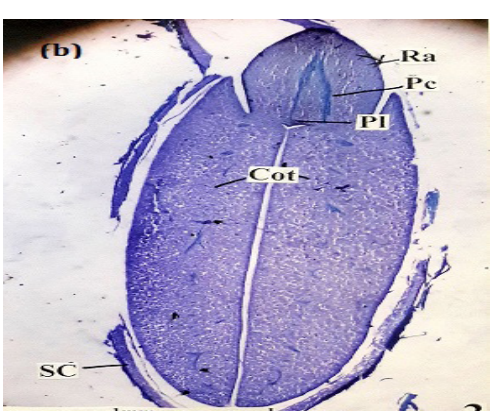

(b)

Figure 3. (a) Vertical section of the seed, at right angles to the surface. (b) Cotyledons and radicle in LS of the seed (Cot-Cotyledons; Pe-Procambium; Pl-Plumule; Ra-Radicle; SC-Seed coat).

$\mathrm{mm}$ long and $8 \mathrm{~mm}$ thick, while the radicle was thick and conical with $15 \mathrm{~mm}$ height and $10 \mathrm{~mm}$ thickness (Figure 5(b)). Procambial strand was seen in the radicle and plumule was minute and occurs in between cotyledons (Figure 3(b)). The cells of the cotyledons are thin walled, polyhedral and are darkly strained. The cells contain many cell inclusions, the starch grains being the majorcontent. 


\subsubsection{Seed Coat}

The wood apple seed coat (Testa) consists of three zones. The outer zone had one or two layers brachyscelerids with lignified walls (Figure 4(a)). From the scelerotic layer several conical bundles of hairs arose which were tightly held and conical in shape. The surfaces of the tufts of hairs were irregularly bulged (Figure 4(b)). The trichome bundles were up to $20 \mathrm{~mm}$ long. The middle part of the seed coat was thin and includes three or four layers of tangentially elongated parenchyma cells and discontinuous small clusters of lignified scelerids. The inner zone of the seed coat was parenchymatous (sarcotesta) (Figure $5(a))$. It includes six or seven layers of circular thin walled compact cells with dense cells inclusions. The innermost layer of the parenchymatous seed coat forms a thin layer of epidermis. The total thickness of seed coat was 200-300 $\mu \mathrm{m}$. Along the boundary of the middle seed coat occurs a layer of calcium oxalate crystals (Figure 5(c)). The crystals were prismatic type. The crystalliferous layer consists of two or three rows of crystals and the layer was continuous all along the seed coat.

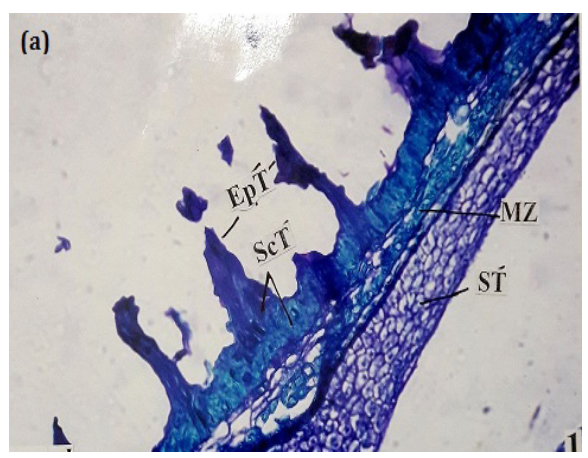

(a)

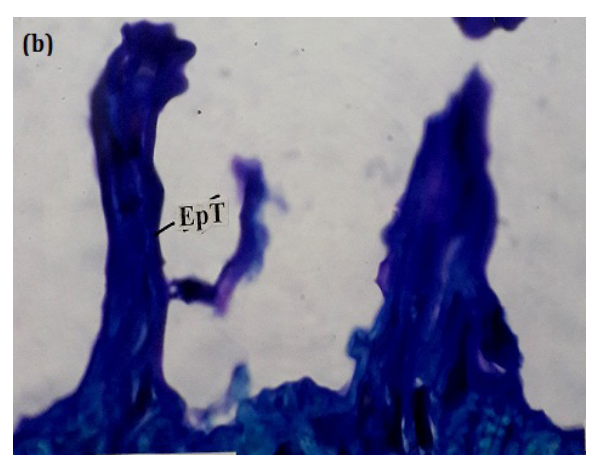

(b)

Figure 4. (a) Outer sclerotic seed coat with vertical bundles of epidermal trichomes. (b) Two trichome bundles enlarged (EPT-Epidermal trichome; MZ-Middle zone; SCT-Sclerotic tissue; Pa Sc- Parenchyma seed coat).

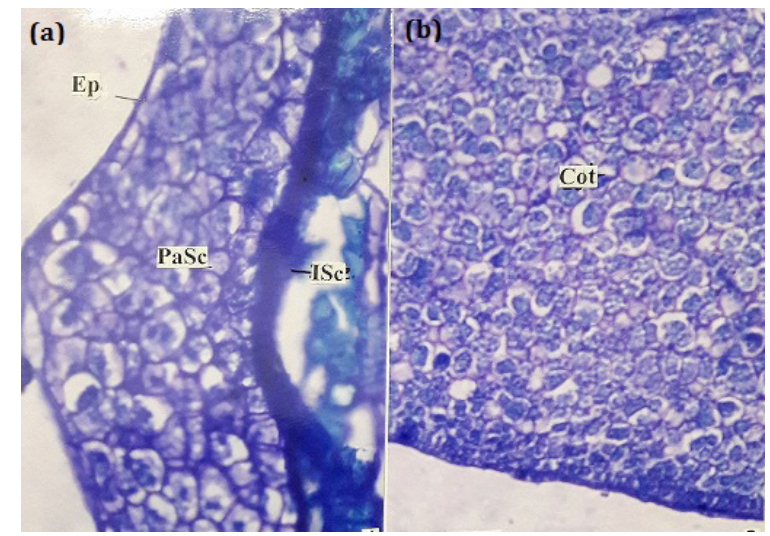

(a)

(b)

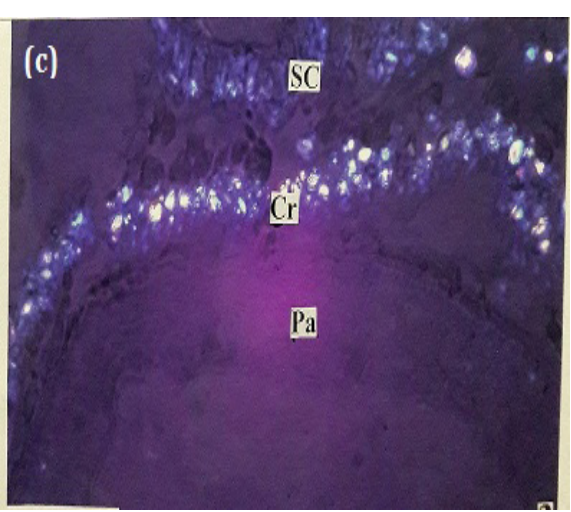

(c)

Figure 5. (a) Parenchymatous seed coat. (b) Cotyledonary cells. (c) Crystals in the seed Coat (Cr-Crystals; PaParenchyma; SC-Seed coat; Cot-Cotytedous; Cr-Crystals; EP-Epidermis; IMS-Inner seed coat).

\section{Conclusion}

The result of the investigation provide useful data that can be used to develop necessary equipment and machines for planting, shelling, conveying, drying, aeration, storing and oil extraction from WAS. In brief, physical properties and anatomical characterisation of Wood Apple Seeds, enlarge the knowledge about the species and providing useful data for its industrial processing.

\section{Acknowledgement}

This work was financially supported by Grant-in-Aid under Directorate of Extramural Research and Intellectual Property Rights (ER\&IPR), Defence Research Development Organization (DRDO), Ministry of Defence, Government of India. 


\section{References}

1. Allen BM. Malayan fruits. An introduction to cultivated species. Singapore: Donald Moore Press Ltd; 1967.

2. Khare CP. Indian medicinal plants: An illustrated dictionary. Springer Science. Germany: Springer Verlag, Berlin/ Heidelberg. 2007. p. 453.

3. Darsini DTP, Maheshu V, Vishnupriya M, Nishaa S, Sasikumar JM. Antioxidant potential and amino acid analysis of underutilized tropical fruit Limonia acidissima L. Free Rad Antiox. 2013; 3:S62-9.

4. Morton J. Wood-Apple. In: Morton JF, editor. Fruits of Warm Climates; Miami, FL. 1987. p. 190-1.

5. Khewkhom N, Greger H, Shangchote S. Antimicrobial activity of 16 plant extracts of the Rutaceae family against phytopathogenic fungi. Agricultural Sci J. 2008; 39:119-23.

6. Adikaram NKB, Abhayawardhane Y, Gunatilaka AAL, Bandara BMR, Wijeratne EMK. Antifungal activity, acid and sugar content in the wood apple (Limonia acidissima) and their relation to fungal development. Plant Pathology. 2007; 38:258-65.

7. Gupta R, Johri S, Saxena AM. Effect of ethanolic extract of Feronia elephantum Correa fruits on blood glucose level in normal and streptozotocin-induced diabetic rats. Natural Product Radiance. 2009; 8:32-6.

8. Peter KV. Underutilized and under exploited hortcultural crops. New Delhi: New India Publishing Agency; 2008.

9. Gomez MI, Obilana AB, Martin DF, Madzramuse M, Monyo ES. Manual of laboratory procedures for quality evaluation of sorghum and pearl millet. International CROP RESEARCH Institute for the Semi-Arid Tropics, ICRESTAT; Andhra Pradesh, India. 1997.

10. Nalladulai K, Alagusundaram K, Gayathri P. Airflow resistance of paddy and it's by products. Bio-Systems Engineering. 2002; 83:67-75.

11. Sirisomboon P, Kitchaiya P, Pholpho T, Mahuttanyavanitch W. Physical and mechanical properties of Jatropha curcas L. fruits, nuts and kernels. Biosystems Engineering. 2007; 97:201-7.

12. Mohsenin NN. Physical properties of plant and animal materials. 2nd ed. New York, USA: Gordon and Breach Science Publishers; 1980. p. 238-41.

13. Mohsenin NN. Physical properties of plant and animal materials. New York: Gordon and Breach Science Publishers; 1970.

14. Kiani KDM, Minaei S, Maghsoudi H, Varnamkhasti MG. Moisture dependent physical properties of red bean (Phaseolus vulgaris L) grains. Int Agrophysics. 2008; 22:231-7.
15. Mohsenin NN. Physical properties of plant and animal materials. 2nd ed. New York: Gordon and Breach Science Publishers; 1986.

16. Maduako JN, Faborode MO. Some physical properties of cocoa pods in relation to primary processing. Ife Journal of Technology. 1990; 2(1):1-7.

17. Ozarslan C. Physical properties of cotton seed. Biosyst Eng. 2002; 83(2):169-74.

18. Jain RK, Bal S. Properties of pearl millet. J Agricultural Engineering Research. 1997; 66:85-91.

19. Sass JE. Elements of botanical micro technique. New York: McGraw Hill Book Co. 1940. p. 222.

20. Johansen DA. Plant micro technique. New York: Mc Graw Hill Book Co. 1940. p. 523.

21. O'Berien TP, Feder N, Mc Cuicll ME. Polychromat staining of plant cell walls by toluidine blue blue-O. Protoplasma. 1940; 59:364-73.

22. Esau K. Plant anatomy. New York: John Wiley and Sons; 1964. p. 767.

23. Palaniswamy KP, Muthukrishna CR, Shanmugavelu KG. Physicochemical characteristics of some varieties of mango. Indian Food Packer. 1974; 28(5):12-8.

24. Hemavathy J, Prabhakar JV, Sen DP. Drying and storage behavior of mango (Mangifera indica) seeds and composition of kernel fat. Asean Food Journal. 1988; 4(2):59-65.

25. Uchoa-Thomaz AMA, Eldina CS, Jose OBC. Chemical composition, fatty acid profile and bioactive compounds of guava seeds (Psidium guajava L.). Food Sci Technol, Campinas. 2014; 34(3):485-92.

26. Bal LM, Ahmad T, Senapati AK, Pandit PS. Evaluation of quality attributes during storage of guava nectar $\mathrm{Cv}$ Lalit from different pulp and TSS ratio. Journal of Food Processing and Technology. 2014.

27. Patel RK, Maiti CS, Deka BC, Deshmukh NA, Roy D. Variability studies in Guava (Psidium guajava L.) genotypes for growth, yield and quality attributes at mid-hills of Meghalaya. Journal of Hill Farming. 2011; 24:24-8.

28. Tunde-Akintunde TY, Akintunde BO. Some physical properties of sesame seed. Biosystems Engineering. 2004; 88(1):127-9.

29. Coşkuner Y, Karababa E. Physical properties of coriander seeds (Coriandrum sativum L). J Food Eng. 2007; 80:408-6.

30. Zewdu AD, Solomon WK. Moisture-dependent physical properties of tef seed. Biosyst Eng. 2007; 96(1):57-63.

31. Ixtaina V, Nolasco SM, Tomas MC. Physical properties of chia (Salvia hispanica L.) seeds. Ind Crops Prod. 2008; 28:286-93.

32. Damian C. Physical properties of mustard seeds (Sinapis alba L). Lucrări Ştiinţifice - Seria Zootehnie. 2014; 61:39-44. 
33. Joshi DC, Das SK, Mukherjee RK. Physical properties of pumpkin seeds. J Agric Eng Res. 1993; 54(3):219-29.

34. Felix UO, Anthony OA. Determination of some physical properties of African yam beans. The Pacific Journal of Science and Technology. 2011; 12:374-9.

35. Seifi MR. Moisture-dependent physical properties of sunflower seed (SHF8190). Mod Appl Sci. 2010; 4:135-43.

36. Ashwini T, Vikas L. Effect of moisture content on the physical properties of sunflower seeds (Helianthus annuus L.) for development of power operated sunflower seed decorticator. International Journal of Science and Research. 2014; 3(7):2298-302.

37. Jouki M, Khazaei N. Some physical properties of rice seed (Oryza sativa). Research Journal of Applied Sciences, Engineering and Technology. 2012; 4(13):1846-9.

38. Ghamari S, Khosro M, Abdolvahed K, Hadi G. Evaluation the some physical properties of chickpea seeds in kurdistan region of Iran. International Journal of Agriculture and Forestry. 2014; 4(3A):4-7. 